\title{
THE AFFECT OF PROJECT-BASED ACTIVITIES ON EFL LEARNERS' SPEAKING SKILLS
}

\section{RESEARCH ARTICLE}

\section{Feyza Nur EKIzER ${ }^{1}$}

1 Asst. Prof. Dr., Necmettin Erbakan Üniversitesi, Yabancı Diller Yüksek Okulu, Konya, fyznur@hotmail.com, ORCID: 0000-0003-0568-5355.

\begin{abstract}
:
Mainly, the criteria among people for someone whether s/he knows a language or not is his adequacy to speak that language. A huge percentage of students attend second-language courses because they want to learn how to speak the language. However, unfortunately, a majority of them cannot or will not be able to do it at the end. The matter for those students is that they may be prosperous in linguistic activities carried out in the classroom, but once outside, they cannot use what they have learnt. Therefore, what can be done to achieve real life communication in a language class room? The purpose of our study was to find out how far Project-based activities affected the speaking skills of the Preparatory Class intermediate level students in the Department Of English Language Teaching at Necmettin Erbakan University. Semi-Structured Interview and Focus Group Discussion was carried out for the 14 participants who attended the classes for one academic term. As the study was Qualitative, Content Analysis was used to analyze the data. The results showed that Project-based activities contributed a lot to the participants' level of spoken fluency and hindered their anxiety to some extent.
\end{abstract}

Keywords: Speaking skills, project-based learning, preparatory class, higher education 


\title{
PROJE TABANLI FAALIYETLERIN EFL ÖĞRENCILERININ KONUŞMA BECERILERINE ETKISI
}

\begin{abstract}
Öz: Temel olarak, insanlar için bir dilin bilip bilinmediğinin ölçütü, o dilin konuşma yeterliliğidir. Öğrencilerin büyük bir yüzdesi dili nasıl konuşacaklarını öğrenmek istedikleri için ikinci dil kurslarına katılıyorlar. Fakat, ne yazık ki, çoğunluğu sonunda bu isteklerini gerçekleştiremiyorlar. Bu öğrencilerin asıl problemi, sınıfta yürütülen dil faaliyetlerinde başarılı olmalarına rağmen dışarı çıktıkları an öğrendiklerini kullanamamalarıdır. Bu nedenle, bir dil sınıfı atmosferinde gerçek yaşam iletişimini sağlamak için neler yapılabilir? Çalışmamızın amacı, Proje-temelli aktivitelerin Necmettin Erbakan Üniversitesi İngilizce Öğretmenliği bölümündeki hazırlık sınıfı orta seviye öğrencilerinin konuşma becerilerini ne kadar etkilediğini bulmaktı. Bir akademik dönem boyunca derslere katılan 14 katılımcı için Yarı Yapısal Görüşme ve Odak Grup Tartışması yapılmıştır. Çalışma Nitel olduğundan, verilerin analizinde İçerik Analizi kullanılmıştır. Sonuçlar, Proje-bazlı faaliyetlerin katılımcıların sözlü akıcılık düzeyine oldukça katkıda bulunduğunu ve kaygılarını bir ölçüde engellediğini göstermiştir.
\end{abstract}

Anahtar Kelimeler: Konuşma becerileri, proje-temelli öğrenme, hazırlık s1nıfı, yükseköğrenim

\section{Introduction}

It is a well-known fact that every individual has the right to take a good education and that the education received has a significant impact on his or her life. The individual, with the help of his/her education, gains new knowledge, skills and experiences; develops personally, socially and economically; organizes his/her daily life and tries to make life more enjoyable for himself/herself. However, it is undoubtedly important to establish the necessary conditions to provide the individual with such a level of education. In particular, there is a need to work on teaching methods or learning pathways continuously and to create new alternatives to meet the differing needs and expectations of students in a rapidly changing and developing world.

One of those alternative methods is the PBL (Project-based learning), whose intellectual basis was established centuries ago and applied for different purposes over time, but is still popular today.

Initially, PBL was designed to overcome a challenge or to solve a problem in the real world. PBL has been understood that it has common features with a number of other learning theories, its impact area has broadened/ it was originally used in certain 
disciplines and for a limited number of students in the past years. However, now it is used in almost all disciplines and for students of all levels, it has a significant impact on student achievement, the student benefits from the knowledge and skills that he/ she acquires in this way for life. It requires collective work as well as individual work and there is a strong belief in educators and business world that it contributes significantly to the development of countries, PBL has started to be perceived differently and continued to increase its importance day by day (Permatasari, 2013).

Considering all these impact areas, this study intends to investigate whether PBL affects students' collaborative learning and contributes to the development of their communication skills in the context of ELT.

\section{REVIEW OF LITERATURE}

\section{What is PBL?}

The idea of working on the projects historically dates back to the 1600s but in the 1960s, due to the circumstances at that time, it was once again in the interest of some scientists working in the field of education.

This time, the importance of involving students in the learning process and allowing them to work actively and independently was emphasized. In fact, there was a common consensus on the definition in such a way that PBL is an instructional approach designed to give students the opportunity to learn new concepts and develop new skills by engaging them in projects and collecting in-depth information. So, they can overcome the challenges and find solutions to the problems they face or are likely to encounter in the real world (Patton, 2012).

Even in the last two or three decades, PBL, mostly in the context of individual learning, began to be associated with many concepts and even used interchangeably such as student-centered, self-interested / motivated / directed learning, inquiry-based learning, constructivist learning, experiential learning that have recently been popular in the field of education.

One of those who set up that relationship is Knoll. He said "A growing number of teachers began to define the project more broadly and considered it to be a viable "general" method of teaching" (Knoll , 1993a).

Another fact showing that PBL is becoming widespread is that: It first began to be applied in certain disciplines and with limited age groups, but then the area of use was extended to all disciplines and students of all levels.

However, this time, it has evolved/turned into collective/collaborative work that is more than individual, where social skills are predominant. 


\section{How does PBL process work?}

In PBL which is a student-centered, process-based and solution-oriented approach, the student is first engaged in the project work process and is asked to discover a challenge or a problem that exists or is likely to exist in the real world. It is then expected to complete the project process by asking questions, discussing ideas, making predictions, designing plans and/or experiments, collecting data and analyzing-synthesizing, drawing conclusions and sharing them with others. In other words, the student collects in-depth information on the project subject/topic by using the knowledge, skills and experiences he/she has during the Project period. While collecting information, he/she develops new skills and learns new concepts with different meanings, which is called PBL in the educational literature (Bereiter \& Scardamalia, 1999).

\section{Characteristics of PBL}

PBL has many characteristics that positively affect teaching and learning. It is an educational methodology that is student-centered, process-based, acquired through inquiry and research, and focused on solution, result or outcome. It removes the student from limited and artificial classroom environments, introduces him/her to the real world and helps them focus on the problems there. In this sense, the student is prepared for the outside world. Students are included in the learning process and are given the right and authority to use their free will in their studies. In this respect, the motivation of the students is quite high. Students, focusing on only the project topic during the project period, use their time and energy more efficiently without distracting their attention into different directions. PBL is an active learning method. It improves student-teacher communication and interaction, students' study results and increases their achievement. It enables students to participate in social environments and improves their communication skills. It also encourages students to learn continuously, as they will be engaged in inquiry and research activities throughout the project process. PBL provides internal discipline and improves management skills in students besides increasing students' knowledge of content, improving their knowledge-handling skills, and helping them gain more rewarding experiences (Thomas \& Mergendoller, 2000).

In addition to acquiring deep content knowledge, students develop and use many 21st century skills such as critical thinking, problem solving, communicating, collaborating, planning and managing. Students use these skills throughout their lives. It can be designed for a single discipline or joint for multiple disciplines. In this context, joint work and interdisciplinary coordination may be required. Achievements within the scope of the projects are inspiring for the students' future studies and increase their desire to learn new things. It provides students with opportunities for feedback and revision of the plan and project. Within the scope of the project, students are required to present the problems, research process, methods and results they encounter. In this respect, PBL is a method open to the public. 
In short, from all these facts, we see PBL as a method that helps students significantly improve their learning knowledge and skills, use what they learn and achieve their goals in the field of education.

\section{Learning theories supporting PBL}

From our research, it is understood that PBL was designed in the 1960s and is based on the experiences of a student in a real-world challenge or problem. However, when the research studies in the context of learning theories are examined, many approaches that support the idea of PBL are realized.

First of all, Edutopia associates PBL with John Dewey's philosophy of education, who is one of the most influential thinkers in the history of modern educational theory, strongly believes that education in schools should be based on the principles of "learning by doing and advocates the " hands on " approach in education and expresses his opinion together with William Kilpatrick as "project-based learning has its origins back in the work of John Dewey and William Kilpatrick and dates back to 1918 when the term was first used" (Edutopia, 2014).

Again, we understand that the PBL approach is similar to Kolb's definition of "Learning is the process by which knowledge is created through the transformation of experience". Another resemblance is seen in Piaget's constructivist theory which argues that people produce knowledge and form meaning based upon their experiences. There are also other learning theories that support PBL approach. One of them is Problem-based learning, which has features that can almost be used in place of the project-based learning approach, and is described as "a teaching method in which complex real-world problems are used as the vehicle to promote student learning of concepts and some skills such as critical thinking, problem-solving and communication skills." (Duch et al, 2001) The other is "inquiry-based learning" where learning takes place in a process, the student takes an active role in the process, and a way of learning based on inquiry and research is adopted.

Besides the above mentioned approaches, there is also task-based learning, defined by Nunan as a class work that enables students to understand, use, produce, or interact in the target language. (Nunan, 2004) Although the main goal in a foreign language learning is communication and interaction, students are also expected to enter the individual learning mode after all. Candy (1991), for instance, argues that Self-directed learning covers four domains including personal autonomy, selfmanagement, independent pursuit of learning, and learner-control, all of which are crucial to foreign language learning. Benson (2011) maintains that language learners are urged to control their learning.

Again in the context of individual or collaborative learning, Knowles describes Self-directed learning as "In its broadest meaning, self-directed learning describes a 
process in which individuals take the initiative, with or without the help of others, in diagnosing their learning needs, formulating learning goals, identifying human and material resources for learning, choosing and implementing appropriate learning strategies, and evaluating learning outcomes."(Knowles, 1975, p. 18) Although there are some slight differences between the above-mentioned approaches, they have a lot in common and overlap with the PBL. Namely; they include a modern education philosophy and are student-centered. The student is active and has high learning motivation. They are given the opportunity to work comfortably and freely and provide the student with human characteristics such as curiosity of learning, sense of mastery, goal setting and managing the process. Learning takes place in a process through real-world experiences and the student is engaged in the whole process (Patton, 2012).

In the learning process, many skills of the 21st century are developed and used by students. They use these skills throughout their lives. Learning is assessed not only through knowledge but also through skills. They improve students' high-level thinking, producing, presentation or defence skills via collective and individual work.

As a result, all of the above-mentioned features do not contradict with the PBL, but support it. Therefore, we can easily say that PBL is supported by the scientific world and is a valid method today.

\section{Collaborative Learning}

Besides individual learning, PBL also includes working with others. Soloman explains this as follows:

"In PBL, students collaborate in groups to solve authentic and curriculum-based problems, and decide how to approach a question and what activities to pursue" (Solomon, 2003).

Learning through the project includes collective studies as well as individual studies, and even makes sense and gains value with them. Individual studies are predominant in PBL, but in the project period, students also need the support of their teachers in the sense of facilitating the work they do, as well as evaluate the results of the project together and share them with the wider audience. In this sense, PBL method, includes individual work as well as teamwork.

However, this study includes more of a collective, communicative, collaborative, interactive side of the students and the method forementioned.

\section{METHODOLOGY}

This study was implemented with 14 English Language Teaching Preparatory Class students studying at Necmettin Erbakan University. It was a 4-month study carried out in the first semester of the 2019/2020 academic year. The tools made use of for the research were Focus Group Discussion and Semi-structured interview. 
One purpose of the study is to find answers to the following research questions:

1. What is the nature of the relationship between project-based learning and speaking skills?

2. What are the student teachers' perspectives towards project based learning?

3. In what ways do the collaborative project-based activities affect communicative skills?

\section{Procedure}

At the beginning of the term the students were told that the course would involve communicative activities in which they were required to discuss, do pair-work, group work, plan a task and carry it out, do oral presentations and specifically work together on projects which again had to be put forward in the class.

Every three hours a week the students were given topics of discussion which they themselves chose in Focus Group Discussion groups of seven. The topics were of group interest and of the problems students thought needed solutions. They were written down as a rapport in which the reasons of choice were stated.

The class was divided into three groups (5-5-4) and explained that each group had to select four problems/topics of interest from their list and design a project in which they tried to find solutions/reasons to them.

Each week, besides different communicative activities, three hours of class was spared for the discussions. The project-based topics were handed in to the researcher (in this case the teacher of the class) for supervision. They were told that they could change the topics, if necessary, during the term.

The projects the students had a concensus on were:

1. Class Newspaper

2. A Movie Poster

3. Surveys (creating, administering, reporting)

4. New Inventions (creativity)

Four projects were totally carried out during the term. These were presented once in four weeks by the three groups.

\section{Population and Sampling}

This study was put through with 14 Preparatory class students attending English Language Teaching Department of Necmettin Erbakan University in Konya. In terms of sampling, Convenience sampling, in which the participants are chosen based on their relative ease of access, was used (Wiederman, 1999). The 14 students were neither 
told about the research being carried out and nor about the purpose of the activities during the process.

\section{Data Collection}

In this study, in order to collect data, two different instruments were utilized. These are semi structured interview and focus group discussions. Here, the interview type chosen is semi-structured in which the interviewees (in this case students) are asked open-ended questions at the end of the one-term research application procedure. Within this process, six pre-prepared guiding questions were directed to the students following the Focus Group Discussions and their responses were transcribed by the researcher. Focus Group Discussions (FGDs) are defined as semi structured group discussions, which bring forth qualitative data on the group level by triggering off interaction between participants. In addition, they can be made use of to explore the meanings of survey findings which cannot be explained statistically, the range of opinions, opinions on a topic of interest and to gather a wide variety of local terminology. Following the performance of the focus group discussions, the key findings were defined, analyzed and put down on paper as a report.

\section{Data Analysis}

Stake (1995) illustrates analysis as a matter of giving meaning to first impressions as well as to final compositions, and interpreting our first impressions. According to Dörnyei (2007), content analysis has lately become relevant with qualitative research as it refers to a second-level, interpretive analysis of the underlying deeper meaning of the data. Through a very long process of content-analysis implemented with in-depth attention, the results found were interpreted for each participant.

The semi-structured interview and the FGD rapports were assessed via the strategies in qualitative data analysis, which are categorizing, coding, and interpreting. Coding is the procedure in which the researcher sorts out the collected data into meaningful chunks after checking it in detail and tries to figure out what it would mean conceptually. These parts may be a word, a sentence, a paragraph or even a whole page of data (Yildırım and Simsek, 2013).

Single researchers should find someone else to cross-check his/her codes for what is called inter-coder agreement (or cross-checking) (Creswell, 2013). Such an agreement might be predicated on whether two or more coders compromise on codes used for the same passages in the text. It is not that they label the same code for the same passage of text but whether another coder would code it with the same or a similar code. In this study, an independent colleague was consulted to help code the question and answers. The consistency of the coding was $90 \%$ on average. Miles and Huberman (1994) suggested that the consistency of the coding should be in agreement at least $80 \%$ of the time for good qualitative reliability. As a result, the questions prepared for the 
interview were categorized into themes and the open codes were found and given in accordance with the given answers.

\section{Findings and Discussion}

The interview questions directed to the students at the end of the term and after a whole 16-week of consciously implemented activities were:

1. In what ways do you think the in-class discussion and speaking activities affected your language use? Did you feel the aid of them in your project presentations?

2. Do you believe that the collaborative speaking activities provided you with accurate and fluent speaking?

3. Did the project-based activities supply you with information and support during the speaking process? Please explain and exemplify.

4. Do you think that the PBL activities had an impact on your pronunciation?

5. How did the PBL activities make you feel during the communication process? Did you feel the peer-support through the process?

6. PBL based speaking activities as a group or individual speaking activities? Which one do you think helps you improve your speaking skills? Please give reasons.

These interview questions were applied to the 14 students and their answers were documented. For each question the interviewees were required to think deeply and give real, sincere replies. According to the students' answers themes were formed under which codes were given for better analysis of data. The themes were coded as in Table 1, 2 and 3.

Table 1. Focus on outcome and product theme results

\begin{tabular}{|l|l|}
\hline Focus on outcome and product & Repetitions \\
\hline Producing & 11 \\
\hline Purposeful tasks & 9 \\
\hline Need to create & 10 \\
\hline Lots of things to do & 10 \\
\hline
\end{tabular}

In reference to the interview questions directed to the students, the first theme formed was 'Focus on outcome and product'. Within this theme four codes were obtained. Two of the six questions had the purpose of evaluating these codes. When the answers of the students were examined in detail, the code 'producing' was encounte- 
red 11 times, while the codes and 'need to create' and 'lots of things to do'were encountered 10 times and 'purposeful tasks' 9 times. As it can be clearly seen, the repeated codes showed that most of the students thought the PBL activities forced them to be creative, gave them a target and an aim to achieve, required them to be productive while giving them lots of things to do before, during and after the tasks.

Some of the student responses for this theme were:

'I never thought that I would be this creative, in a way, the projects revealed the real me inside.'

'We never had spare time, it seemed that we always had to do something.'

'Producing something really made me happy, both in terms of oral practice and a real product at the end.'

From their answers it is quite obvious that the students in general were fond of the PBL activities and the majority thought it gave them a chance to discover and express themselves in a way they had never done before.

Table 2. Student collaboration and interaction theme results

\begin{tabular}{|l|l|}
\hline Student collaboration and interaction & Repetitions \\
\hline Distribution of duty among students & 15 \\
\hline Excessive talk to other students in group & 16 \\
\hline Peer support among group members & 12 \\
\hline
\end{tabular}

According to the second theme 'Student collaboration and interaction', three different codes were determined. This theme was formed in order to assess the social interaction and collaboration of the students aforementioned. The codes under the theme were again created in accordance with the students' answers. The duty distributed among the students, and how fair it was, was mentioned 15 times, while the amount of talk the students had with other group members was repeated 16 times. Also, the word 'peer-support' among the members of the group had a repetition of 12 times. These results showed that the students felt really social and had the opportunity to interact with group members while getting the support of their peers when needed during the activities.

Some student answers for this theme were:

'All of us had equal duties, a better student was not in front of the other and noone was left behind.'

'We had a lot of time to talk to each other and speaking practice was great.' 
'Everybody helped eachother when the other needed something, working as a group really taught me many things like when I got stuck on a subject, one of my friends immediately tried to help me.'

As it can be understood from their own speeches, students felt that the activities carried out within and without the class were of splendid occasion for them to collaborate, cooperate and interact.

Table 3. Language skills related development theme results

\begin{tabular}{|l|l|}
\hline Language skills related development & Repetitions \\
\hline Speaking more fluently & 14 \\
\hline Need to learn new vocabularies & 13 \\
\hline Coherence & 8 \\
\hline Express and present information & 11 \\
\hline
\end{tabular}

The third and the final theme of the study was a broader term called 'Language skills related development'. Within this theme the codes formulated were of the development of different language skills of the students. 14 times repeated was the code 'fluency' and how students thought they spoke more fluently. The next code was the lack of vocabulary, student replies showed 13 times repetition of how inadequate they felt in terms of vocabulary. 8 times replied was the following code 'coherence' in which students remarked that they became more aware of studying with others in harmony and also gathering information and putting it together in coherence. The last code was expressing and presenting information where students found occasions to discover themselves and overcome their stage anxiety in front of their classmates. This ultimate code was repeated 11 times in the students interview responses.

A few examples of real student responses for the final theme were:

'I wanted to talk more actually but my word knowledge was not enough, so these activities proved that I needed to learn more vocabulary and how insufficient my vocab was.'

'I really can't believe the progress in my speaking skills, at the end of the term I can clearly see and feel the difference in my speeches. I am for sure much more fluent in English.'

'It was my first time to make a presentation in front of an audience. At first I was so anxious and shy but in the second presentation, I felt more calm and courageous.' 
Here, we can see that most of the students made a visible progress in different language skills besides realizing their inadequate parts when their first person statements are examined.

\section{Pedagogical Impacts}

From the above explanations, PBL approach has led to some methodological changes in education. With PBL, there have been significant changes in the roles of students and teachers in particular. PBL has enabled the student to be more active in the learning process, to work more freely and independently, to plan and manage his / her studies himself / herself. In PBL approach, the student's interest and engagement in the project is considered a basic condition for success. Students, without the need for extra help from outside, work and complete the project in a planned and programmed manner by focusing on the results.

Learning takes place in a process, during activities and in a natural course. There is no specific method for achievements, but the student needs some technical and practical applications to complete the project process, such as asking questions, discussing ideas, predicting results, designing plans, collecting, analyzing and synthesizing data, drawing conclusions, and sharing them with others.

PBL also emphasizes the need for students to develop many communication skills such as critical thinking, problem solving and collaboration. It includes individual work as well as collective work and gives the student the pleasure of getting the results of the project and sharing it with other people after a long period of intensive work.

As for the changes in teacher roles, a teacher who wants to apply the PBL approach in his/her classroom needs to be more creative in the project preparation process by associating the content with real-world challenges or problems rather than taking ready-made programs and materials off the shelf and using them. In fact, since project work requires collective work, the teacher may feel the need to work with many colleagues or groups of professionals when determining the project topics.

However, how the teacher works with students, the most important actor in the PBL approach, is crucial. In this context, the first thing that the teacher should do is to build trust in the students and make them believe in the project work. In order to increase student independence and ensure growth, the teacher often needs to ask students open-ended research questions in class activities, helps them gain team spirit, and constantly emphasizes the importance of quality. In order to assist students and facilitate their project work, the teacher needs to carry out tasks with the students such as setting up the project team and program, organizing tasks, adjusting the timing, setting control points, finding and using resources, finalizing the project and sharing the outputs with the public. 


\section{Conclusion}

It can be clearly understood from the above mentioned findings and impacts that PBL has a great and undeniable affect on the students' communicative, social, interactive skills besides providing more motivation, less anxiety and a positive attitude towards learning the language as also stated in related research (Dewi, 2016). The teacher organizes various activities in which students can receive support to achieve their project objectives. They have the opportunity to understand, think, question and discuss through PBL activities. Following the completion of the project process, students' gains in terms of knowledge and skills are evaluated in different ways. The project results, outputs or products are shared with the public in various activities. Finally, students' achievements are celebrated and rewarded with wide participation.

In short, from the above explanations, we understand that PBL, as an alternative in the modern education system, creates differences especially in the roles of teachers and students, leads the teachers to be more innovative and creative, enables students to work more comfortably and freely in the learning process. We also understand that students achieve the learning skills they need in the 21st century, and reduce the anxiety of the future through their gains.

\section{Conflicts of Interest}

The author has not declared any conflicts of interests.

\section{References}

BENSON, P. (2011). What's new in autonomy? The Language Teacher, 35(4), 15-18. 2016.

BEREITER, C. \& Scardamalia, M. (1993). Surpassing ourselves: An inquiry into the nature and implications of expertise. Chicago: Open Court.

BLUMENFELD, P., Soloway, E., Marx, R., Krajcik, J., Guzdial, M., \& Palincsar, A. (1991) Motivating project-based learning: Sustaining the doing, supporting the learning. Educational Psychologist, 26 (3\& 4), 369-398.

BRUMFIT, C. J. (1984). Communicative methodology in language teaching: The roles of fluency and accuracy. Cambridge: Cambridge University.

CAMPBELL, C. (2014). Problem-based learning and Project-based learning, Teacher, ACER.

CANDY, P. C. (1991). Self-direction for lifelong learning. A comprehensive guide to theory and practice. Adult Quarterly Education, 42(3), 192-193.

COUNCIL of Europe (2001). Common European Framework of Reference for Languages: Learning, teaching, assessment. Cambridge: Cambridge University.

CRESWELL, JW. (2013). Research design: qualitative, quantitative, and mixed methods approaches. 4th ed. 
The Affect of Project-Based Activities on EFL Learners' Speaking Skills

DE GRAAFF, E. And Kolmos, A., (2007). Management of Change: History of Problem-based and Project-based Learning, P: 1-8.

DEWEY, J. (1916). Democracy And Education: An Introduction To The Philosophy of Education. New York: Macmillan.

DEWEY, J. (1938). Experience and education. New York: Macmillan.

DEWI, H. (2016). Project-based Learning Techniques To Improve Speaking Skills. English Education Journal (EEJ), 7(3),341-359.

DICKINSON, L. (1987). Self-Instruction in Language Learning. Cambridge: Cambridge University.

DORNYEI, Z. (2007). Research Methods in Applied Linguisitics. Quantitative, Qualitative and Mixed Methodologies. Oxford.

KATZ, L., Chard, S.C \& Kogan, Y. (2014). Engaging Children's Minds: The Project Approach, 3rd Edition: The Project. Westport: Praeger.

KILPATRICK, W. H. (1918). The project method. Teachers College Record, 19, 319-335

KILPATRICK, W. H. (1927). School method from the project point of view. In M. B. Hillegas (Ed.), The Classroom Teacher (pp. 203-240). Chicago: Teacher Inc.

KNOLL, M. (1997). The project method: Its vocational education origin and international development. Journal of Industrial Teacher Education , 34(3), 59-80.

KOLMOS, A. and de Graaff, E., (2007). Process of changing to PBL. In: E. de Graaff and A. Kolmos, eds. Management of change: implementation of problem-based and project-based learning in engineering. Rotterdam: SENSE Publisher, 31-44.

KRAJCIK, J.S. \& Blumenfeld, P. (2006). Project-based learning. In Sawyer, R. K. (Ed.), the Cambridge handbook of the learning sciences. New York: Cambridge.

LARMER, J. (2014). Project-based learning vs. problem-based learning vs. X-BL. Retrieved from http://www.edutopia.org/blog/pbl-vs-pbl-vs-xbl-john-larmer

LITTLEWOOD, W. (1981). Communicative Language Teaching: An Introduction. Cambridge University Press.

LOYENS, S. and Gijbels, D., (2008). Understanding the effects of constructivist learning environments: introducing a multi-directional approach, Instructional Science, 36, 351-357.

LYNN M. Burlbaw, Mark J. Ortwein and J. Kelton Williams (2013). The Project Method in Historical Context. SENSE.

MCLEOD, S. A. (2017, Oct 24). Kolb - learning styles. Simply Psychology. https:/ / www.simplypsychology.org/learning-kolb.html

MILES, MB. and Huberman, AM. (1994). Qualitative Data Analysis. Sage.

NUNAN, D. (2004). Task-Based Language Teaching. Cambridge: Cambridge University. 
PERMATASARI, S. F. (2013). Improving students' speaking skill through Project-Based Learning for second graders of SMPN 1 Kawedanan, Magetan. Unpublished Bachelor's thesis. State University of Malang, Malang.

PATTON, A. (2012). Work that matters: The teacher's guide to Project-Based Learning. The Paul Hamlyn Foundation. Unpublished.

PHYLLIS, C. Blumenfeld, Elliot Soloway, Ronald W. Marx, Joseph S. Krajcik, Mark Guzdial, and Annemarie Palincsar (1991). Motivating Project-Based Learning: Sustaining the Doing, Supporting the Learning, Educational Psychologist, 26(3\&4), 369-398.

RICHARDS, J. C. (2005). Communicative language teaching today. Singapore: RELC.

SAVERY, J. R. (2006). Overview of problem-based learning: Definitions and distinctions. Interdisciplinary Journal of Problem-based learning, 1(1).

STAKE, R. 1(995). The Art of Case Study Research. Sage.

THOMAS, J. W. \& Mergendoller, J. R. (2000). Managing project-based learning: Principles from the field. Paper presented at the Annual Meeting of the American Educational Research Association, New Orleans.

ULRICH, C., (2016). John Dewey and project-based learning: Landmarks for nowadays Romanian education, Journal of Educational Sciences \& Psychology, VI (LXVIII), 54-60.

WILLIS, J. (1998). Task-Based Learning: What Kind of Adventure?, The Language Teacher-Issue 22(7).

WIEDERMAN, MW. (1999). Volunteer bias in sexuality research using college student participants. J. Sex Res. (36), 59-66.

YALDEN, J. (1981). Communicative Language Teaching: Principles and Practice. OISE .

YILDIRIM, A. \& Simsek, H. (2013). Sosyal Bilimlerde Nitel Araştırma Yöntemleri. Seçkin, Ankara. 